\title{
(๗) IJBEMP
}

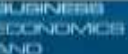

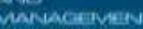

International Journal of Business, Economics and Management Perspectives

Uluslararası İşletme, Ekonomi ve Yönetim Perspektifleri Dergisi

Yıl: 3, Cilt:2, Sayı: 2, Temmuz 2018, s. 16-28

BİLİNÇLI FARKINDALIK (MINDFULNESS): KAVRAMSAL BİR İNCELEME

\section{Dr. Öğr. Üyesi Tahsin AKÇAKANAT}

Süleyman Demirel Üniversitesi İIBF İşletme Bölümü

tahsinakcakanat@sdu.edu.tr

Arş. Gör. Serpil KÖSE

Isparta Uygulamalı Bilimler Üniversitesi Yalvaç Büyükkutlu Uygulamalı Bilimler Yüksekokulu serpilkose@isparta.edu.tr 


\title{
BİLINÇLİ FARKINDALIK (MINDFULNESS): KAVRAMSAL BİR İNCELEME
}

\begin{abstract}
$\ddot{\mathbf{O} z}$
Bilinçli farkındalık, yaklaşık 50 yıldır üzerinde araştırmalar yapılan bir kavram olarak yazında yerini almıştır. Kısaca kabullenici ve yargılayıcı olmayan bir tavırla ana odaklanmak, dikkati toplamak olarak tanımlanabilen kavram üzerinde, özellikle psikologlar, psikiyatristler ve eğitim bilimciler çokça durmakta ve çeşitli araştırmalar gerçekleştirmektedirler. Budizm öğretisi gibi doğu meditasyon geleneklerinden kaynaklanan kavram, aslında hiçbir dini ya da felsefi akımla bağlantılı değildir. Bu çalışmada bilinçli farkındalık kavramı, pozitif psikoloji ekseninde ele alınmış olup, hem bireylerin hem de örgütlerin başarıya ulaşmaları açısından önemi irdelenmiştir. Bilinçli farkındalığa temel oluşturan kişilik özellikleri, bilinçli farkındalık stratejileri ve dayandığı kuramsal temeller, bilinçli farkındalık boyutları ve temel tutumlar gibi konular bağlamında açıklamalarda bulunulmuştur. Yine ulusal yazın taraması kapsamında ulaşılan eserlere ilişkin değerlendirmeler de bu çalışma kapsamında yapılmıştır. Çalışma kapsamında ayrıca, uygulayıcılar ve örgütsel davranış alanı ile ilgili çalışan araştırmacılara da önerilerde bulunulmuştur.
\end{abstract}

Anahtar Kelimeler: Bilinçli Farkındalık, Öz-yeterlilik, Ana Odaklanmak, Örgütsel Davranış

MINDFULNESS: A THEORETICAL REVIEW

\begin{abstract}
The concept of mindfulness, investigated for about 50 years, has been taken its place in the literature. Shortly, focusing and accepting the present moment without judgement with full attention, especially the term is examined and researched with various studies by psychologists, psychiatrists, and pedagogues. The term, originated from the east meditation traditions, such as Buddhism, has actually no relationship with any religious or philosophical movement. In this study, the concept of mindfulness is investigated in the context of positive psychology and the importance is examined for both individuals and organizations to reach the success. Some basic explanations have been made in terms of personality traits that generate the basis of mindfulness, mindfulness strategies and theoretical framework, dimensions and basic attitudes. Besides, the evaluations related to the studies in the national literature are done within the scope of this study. In addition, in the scope of this study, practitioners and researchers working in the field of organizational behavior have also been advised.
\end{abstract}

Keywords: Mindfulness, Self-Efficacy, Focusing, Organizational Behavior 


\section{GíRiş}

Bireyler, kendilerini doğru ifade edebilmeleri ve karşılarındaki bireyleri de doğru anlayabilmeleri için doğru bir iletişim kurmalıdır. Doğru iletişim, ancak kendini iyi tanıyan bir bireyin kendini en doğru şekilde ifade etmesi ve aynı zamanda da algılama sürecini iyi kontrol edebilen bir birey olarak karşıdan gelen mesajları en doğru șekilde anlaması ile mümkün olabilmektedir. Karşıdan gelen mesaj bazen bir bireyden, bazen de yazılı bir kaynaktan olabilmektedir. Bireye iletilen her türlü mesaj ancak farkındalık ile en doğru şekilde özümsenebilmektedir.

Bireylerin, yaşamlarında başarılı olabilmeleri için, kendilerini iyi tanımaları, güçlü ve zayıf yönlerini iyi bilmeleri ve özellikle zayıf yönlerini kontrol ederek planladıkları sonuçlara ulaşma yolunda gerekli çabaları göstermeleri gerekmektedir. Bireylerin kendilerini iyi tanımaları noktasında bilinçli farkındalık (mindfulness) kavramı ortaya çıkmaktadır. Bilinçli farkındalık kavramının temeli doğu kültürlerindeki meditasyon geleneğine dayanmaktadır. Pozitif psikolojinin son 15 y1l içerisinde yaygınlaşıp ivme kazanması sayesinde, bilinçli farkındalık kavramı da hızla popüler olmuştur. Zaman içerisinde kavramla ilişkili olarak, öncelikle yabancı sonrasında ise yerli alanyazında sıkça araştırmalar yapılmıştır. Ülkemizde gerçekleştirilen araştırmaların son 10 yıl içerisinde yoğunlaştığı görülmektedir.

Bilinçli farkındalık Brown ve Ryan (2003) tarafından, "kişinin dikkatini, şu anda yaşanmakta olanlara, yargılayıcı olmadan ve kabullenici bir şekilde odaklayabilmesi" olarak tanımlanmıştır. Bilinçli farkındalık düzeyi yüksek olan bireyler planlama, planladıkları süreçleri en iyi şekilde yönetme, karşılaştıkları hataları düzeltme ve süreçleri değerlendirmede daha başarılıdırlar. Bilinçli farkındalık, bireyin başarıya ulaşmasına aracılık eden ve öğrenme süreçlerini etkileyen en temel kavramdır. Yoğun çalışma ve eğitim hayatında başarılı olabilmek, planlı ve düzenli bir şekilde amaçlanan hedefe ilerleyebilmek için bilişsel bilgiye sahip olmak günümüzde neredeyse zorunluluk haline gelmiştir.

$\mathrm{Bu}$ çalışmada, günümüzde bireylerin ve dolayısıyla bireylerin içinde bulundukları örgütlerin başarıya ulaşmasında çok önemli etkisi olan bilinçli farkındalık kavramı, kavramsal olarak ele alınıp, pozitif psikoloji perspektifinden değerlendirmelerde bulunulacaktır.

\section{FARKINDALIK VE BİLINÇLİ FARKINDALIK KAVRAMLARI}

Farkındalık (mindfulness), kısaca ana odaklanılması olarak tanımlanabilmektedir. Bir başka ifade ile farkındalık, dikkatin içinde bulunulan ana odaklanması ve içsel yaşantının gözlemlenmesidir. Farkındalıkta, anlık yaşantıların sorgulanmadan kabullenilmesi söz konusudur. Farkındalık kavramının tanımı dikkate alındığında, bu kavramın temel bileşenlerinin ana odaklı dikkat, içsel gözlem, sorgulamamak ve kabullenmekten oluştuğu anlaşılmaktadır. Dikkatin nefes alış verişe, fiziksel algılara, duyulara, hislere ve düşüncelere odaklandığı farkındalık meditasyonları, Doğu ülkelerinde tedavi amaçlı kullanılmaktadır (Devrim Çatak ve Ögel, 2010: 86).

Üstbiliş ise farkındalıktan öte bir kavramdır. İngilizcede "metacognition" terimi ile açıklanan kavram, yapılan çalışmalarda Türkçeye biliş bilgisi, biliş ötesi, metakognitif bilgi, yürütücü biliş, biliş üstü, bilgiyi kullanma yolu, bilişsel farkındalık gibi birçok farklı şekilde çevrilmektedir (Bağçeci vd., 2011: 552). Bu kavramların dışında yapılan çalışmalar incelendiğinde, bilinçli farkındalık ve metabiliş yanında üstbiliş, üstbilişsel farkındalık, bilişsel farkındalık inancı, bilişsel farkındalık, bilişsel farkındalık yaşantısı, üst bellek, bilişsel farkındalık becerileri, yönetimsel beceriler, üst düzey düşünme becerileri ve üst bileşenler kavramlarının da kullanıldığı görülmektedir (Demir ve Doğanay, 2009: 605).

Bilinçli farkındalık kavramı, John Flavell tarafından 1970'li yılların başlarında ortaya atılmış bir kavramdır. Flavell, 1976 yılında yaptığı çalışmasında bilinçli farkındalığın izleme ve düzenleme ögelerinden oluştuğu şeklinde bir tanım yapmıştır (Akın vd., 2007: 657).

Bilinçli farkındalık kavramının temeli, kendi düşüncelerini düşünme fikridir. Metabiliş, daha spesifik olarak, bir kişinin zaten bildiği şeyin, öğrenme süreçlerinin doğru bir şekilde kavranması ve bilginin ne olduğu ile ilgili fikir edinme ve stratejik becerilerini belirli bir duruma nasıl uygulayacağına dair doğru çıkarımlarda bulunma ve bunu verimli ve güvenilir bir şekilde uygulama becerisiyle birlikte birleşen yetenekleridir (Taylor, 1999: 37). Bir başka tanıma göre bilinçli farkındalık, bireyin yalnızca 
yapabildiklerinin değil, yapabileceklerinin de farkına vararak kendine ait stratejiler geliştirme becerisidir. Böylece birey herhangi bir dış etken olmadan kendi kendini harekete geçirebilecek güce sahip olabilmektedir (Akın ve Çeçen, 2014: 96). Kısaca bilinçli farkındalık, kişinin hangi bilgilere sahip olup olmadığının farkında olması, kendi zihinsel aşamalarını kontrol edebilmesi, öğrenmenin sorumluluğunu alması, kendine uygun öğrenme yöntemlerinin farkında olması, kendi kendini değerlendirebilmesi, kendi öğrenme süreçlerini planlaması, izlemesi, denetlemesi ve tüm bu süreçleri en iyi şekilde yönetebilmesi becerisidir (Bağçeci vd., 2011: 552). Bu süreçlerin sağlıklı bir şekilde tamamlanabilmesi için bireyin iyi bir tahmin yeteneğine sahip olması gerekmektedir. Tahmin yeteneği, bireylere zorlukları önceden fark edebilme avantajı sağlayarak, karşılaşacakları zorlukları dikkate alarak planlama yapmalarını sağlamaktadır (Dilci ve Kaya, 2012: 249).

Senemoğlu'na göre bilinçli farkındalık bireyin bir takım soruları kendi kendine sorabilmesini kapsamaktadır. Bu soruları aşağıdaki şekilde sıralamak mümkündür (Akt. Dilci ve Kaya, 2012: 251):

* Bu mevzuyu öğrenmedeki hedefim nedir? Elde etmeyi beklediğim sonuç nedir?

* Bu mevzu ile alakalı bildiklerim nelerdir?

* Ne kadar sürede bu mevzu ile alakalı istediğim bilgilere sahip olabilirim?

* Mevzu hakkında istediğim bilgileri elde edebilmem için izlemem gereken rota ne olmalıdır?

* Hazırlamış olduğum rotada ilerlerken meydana gelebilecek aksaklıkları hangi şekilde düzeltmeliyim?

* Meydana gelen aksaklıkları nasıl keşfedebilirim?

* Tüm bunlar neticesinde elde edeceğim sonuç, ulaşmak istediğim hedefe uygun mu? Uygun olmadığ taktirde ne yapmalıyım?

Bilişötesi en yaygın haliyle iki gruba ayrılmaktadır. İlk grup bilişin bilgisidir ve kişilerin biliş hakkındaki bildiklerini ifade etmektedir. Bu bilgi türleri açıklayıcı bilgi, prosedürel bilgi ve durumsal bilgi olmak üzere üç farklı bilgi türünden oluşur. Açıklayıcı bilişötesi bilgi kişilerin görev yapılarını, hedeflerini ve bireysel kabiliyetleri ile alakalı inançlarını kapsamaktadır. Prosedürel bilgi ise daha çok sezgisel bilgileri içermektedir. Bu bilgi türü stratejilerin nasıl uygulanacağı gibi "nasıl" sorusunun yanıtlarını içerir. Prosedürel bilginin yüksek olması, bireylerin planladıkları aşamaları otomatikleşmiş şekilde yapmalarına ve daha çeşitli stratejiler üretmelerine yardımcı olur. Durumsal bilgi ise açıklayıcı ve prosedürel bilgiyi içerir. Bu iki bilgiye de sahip bireyin bilgileri ne zaman ve hangi amaçlar doğrultusunda kullanılacağı bilgisidir. Durumsal bilgi, planlanan stratejilerin zamanında ve verimli şekilde kullanılmasına olanak tanır (Akın vd., 2007: 658-659). Bilişötesinin ikinci bileşeni ise bilişsel düzenleme becerilerinden oluşur. Bu beceriler için üç temel yeteneğe ihtiyaç vardır. Bu yetenekler planlama, izleme ve değerlendirmedir. $\mathrm{Bu}$ yetenekler sayesinde birey kendini keşfederek, hafiza süreçlerini kontrol altına alabilmektedir (Karakelle ve Saraç, 2007: 89).

Bilişötesi ile bireyde ortaya çıkması beklenen bazı yetenekler söz konusudur. Bu yetenekler Doğanay (1997) tarafından, "kişinin kendisinin ve öğrenme yollarının farkında olması, bilinçli davranma, kendini kontrol edebilme, planlama, nasıl öğrendiğinin farkında olma, kendini düzenleyebilme ve kendi kendini değerlendirebilme" olarak sıralanmıştır (Akın ve Çeçen, 2014: 95).

\section{BİLINÇLİ FARKINDALIĞA TEMEL OLUŞTURAN KIŞiLIIK ÖZELLIKLERİ}

Bilinçli farkındalığın oluşabilmesi için bireylerin bazı özellikleri taşıması gerekmektedir. Bunlardan ilki öz-yeterliliktir. Öz-yeterlilik, bireyin planladığ sonuca ulaşabilmesi için gerekli faaliyetleri düzenleyerek başarılı olabilmesine ilişkin kendi yargısıdır. Bireyin bu yargısı aynı zamanda, bireyin zorluklarla karşılaştığında bu zorluklara karşı tutumunu ve zorlukların üstesinden gelebilme yeteneğini de kapsar. Kısaca öz-yeterlilik, bireyin planladığı amaca ulaşma sürecinde kendine olan inancidır (Ak1llılar, 2013: 277).

Bir diğer özellik öz-yönetimdir. Bireyler, bilişsel farkındalığa sahip olabilmek için ihtiyaç duyduğu yani eksik olduğu alanı ve öğrenme yolunu kendisi seçebilmeli, süreçleri gözlemleyerek değerlendirme yapabilmeli, gerekli gördüğü alanlarda ihtiyaç duyulan düzeltmeleri yapabilmelidir. Bireyin bilişsel süreçlerde başarılı olabilmesi, yönetimi elinde tutması ile yakından ilişkilidir (Doğanay ve Demir, 2011: 2022).

Bilinçli farkındalıkta bireyin aynı zamanda öz-düzenleme özelliğine sahip olması gerekir. Öğrenme, bireyin kendine en uygun stratejileri seçerek bu yöntemleri kendine uygun şekilde 
düzenleyerek uygulamasıyla mümkün olabilmektedir. Öz-düzenlemenin sağlanmasında planlama, organizasyon, denetleme ve değerlendirme stratejilerinde gerekli yeteneklere sahip olunması önemlidir. Bu özellikte bireyin hem kendisi hem de öğrenme süreci hakkında yeterli bilgiye sahip olması gerekmektedir (Doğanay ve Demir, 2011: 2024).

Kendini kabul, bireyin kendi davranış, tutum ve amacını gerçekleştirmeye yönelik motive edici kaynaklarının farkında olması ve onlara karşı olumlu bir his içerisinde olmasıdır. Başka bir ifade ile bireyin kendine ait olumlu ve olumsuz yönlerini tanıması ve her yönüyle kendisi ile barışık olması halidir (Kuyumcu, 2012: 3).

\section{BIILINÇLII FARKINDALIK STRATEJILERİ}

Öz-düzenleme stratejileri veya üstbilişsel kontrol olarak da adlandırılan bu stratejiler, bireyin öğrenme sürecinden öncesi, öğrenme aşaması ve sonraki aşamaları da kapsamaktadır. Bilinçli farkındalık düzeyleri ve becerileri kişiden kişiye farklılık göstermektedir. Bu beceriler öğrenmeyi kolaylaştıran, hızlandıran ve etkili öğrenmeyi sağlayan becerilerdir. Bilinçli farkındalık stratejileri ise öğrenme sürecini etkin şekilde izleme ve yönetme becerileridir. $\mathrm{Bu}$ stratejiler, bireylerin öğrenme sürecini kontrol etmesine, süreçleri uygun şekilde sıraya dizme, planlama, başarısızların farkına varma, bu başarısızlıklar karşısında nelerin yapılabileceği hakkında kararlar alma ve bu başarısızlıkların üstesinden gelecek taktikler geliştirerek değerlendirme aşamalarını yöneterek öğrenme sürecini etkin şekilde sürdürmelerine olanak sağlar (Demir ve Doğanay, 2009: 608; Karasakaloğlu vd., 2012: 208).

Yapılan araştırmalar incelendiğinde bilinçli farkındalık stratejilerinin dört temel beceriye odaklandığı dikkat çekmektedir. Bunlar tahmin, planlama, izleme ve değerlendirme becerileridir. Tahminde birey, hedefine ulaşmasının ne kadar süreceği ve sonuçlarının ne olacağına odaklanarak sürecin nasıl işleyeceği ve hedefine ulaşma sürecinde karşılaşacağ zorluklar hakkında tahminlerde bulunur. Planlama aşamasında kendisine destek olabilecek etmenleri, hedefine giden yolda nereden başlaması gerektiğini ve en önemlisi bu hedefe ulaşmasının birey için önemini belirler ve izleme aşamasında planladığı adımların sorunsuz şekilde ilerlediğinden emin olur. Değerlendirme aşamasında ise hedeflediği amaca ulaşıp ulaşamadığını ve bu süreçte her aşamanın planladığ ilerlemediğini kontrol eder (Özsoy, 2008: 720-721).

\section{BİLİNÇLİ FARKINDALIK KAVRAMININ KURAMSAL TEMELLERİ}

Bilinçli farkındalık kavramı birçok farklı disiplinle bağlantılı olup, bu disiplinler tarafından üzerinde pek çok çalışma yapılmıştır. Bilinçli farkındalık, "Bilişsel-Davranışçı Terapi, Gestalt Psikolojisi, Psikodinamik Psikoterapi, İnsancil Psikoterapi ve Varoluşçu Psikoterapi” gibi zengin bir kuramsal alt yapıya sahiptir (Özyeşil, 2011: 35). Aşağıda başlıklar halinde bu kuramsal temellerden bahsedilecektir.

\subsection{Bilişsel-Davranış̧̧ı Terapi}

Bilişsel davranışçı terapiler ile farkındalıkta eğitimi verilen başa çıkma yöntemleri birçok yönden benzer özellikler taşımaktadır. Bilişsel terapilerdeki birçok fikir, düşünce sistemi ve teknikler, farkındalık uygulamalarına uyarlanmıştır. Bilişsel terapilerde, dünyayı düşüncelerin var ettiği fikri temel alınmaktadır. Bu da farkındalıkta karşımıza çıkan, düşüncelerin değerlendirilerek kontrol edilmesi gereğini ortaya çıkarmaktadır. Bilişsel terapiler, düşüncelerin ne şekilde ortaya çıktığını anlamaya odaklanmış sistemlerdir. Düşüncelerin ortaya çıkışını ve sonuçlarını inceleyerek zihinlerine nasıl yön verecekleri hususu üzerinde dururlar (Özyeşil vd., 2011: 226).

\subsection{Gestalt Psikoloji}

Gestalt psikolojiye göre içinde bulunulan anı yaşamanın altında yatan manayı anlamak önemlidir. "İçinde bulunulan anda yaşamak" ile "içinde bulunulan an için yaşamak" birbirinden kesinlikle farklıdır. Bilinçli farkındalıkta aslolan, içinde bulunulan an için yaşamak değil, içinde bulunulan anın farkında olmak, o andaki her şeyi doğru şekilde algılayabilmektir. Bilinçli farkındalık duyguları ana göre organize etmez, tam tersine anda yaşananları kabullenmeyi gerekli kılar (Özyeşil, 2011: 36). 


\subsection{Psikodinamik Psikoterapi}

Psikodinamik kuramcılar, bilinçli farkındalıkta olduğu gibi zihnin çalışma şekline odaklanmışlar ve çalışmalarını bu yönde sürdürmüşlerdir. Bilinçli farkındalık ve psikodinamik psikoterapinin ortak noktası buradan kaynaklanmaktadır. Diğer yandan psikodinamik kuramcılar da tıpk1 farkındalıkta olduğu gibi özgürlüğün ancak zihnin sade ve gözlemsel bir farkındalıkla sağlanabileceğini savunurlar. Bilinçli farkındalıkta anı en doğru şekilde algılayabilmenin bir yolu da bu terapide olduğu gibi sade olabilmektir (Ülev, 2014: 7).

\section{4. İnsancıl Psikoterapi}

$\mathrm{Bu}$ kuram, insanların iyi olduğu kadar kötü yönlerinin de olmasını temel almaktadır. İnsanlar iyi yönlerini sevdikleri gibi, kötü veya olumsuz yönlerini de benimsemelidirler. Beğenmediğimiz veya olumsuz gördüğümüz yönlerimiz de aslında bizim bir parçamızdır ve biz bu yönleri aşama aşama kabullenmeyi ve benimsemeyi öğrenmeliyiz. Böylelikle kendimizi dinlemeyi ve gelecek konusunda daha çok endişelenmemeyi öğrenmiş oluruz (Özyeşil, 2011: 16).

Bu kuram, bireyin doğasında olan özelliklerini sağlıklı bir şekilde kabullenmesiyle birlikte daha net ve sağlıklı düşünmesini sağlar. Bilinçli farkındalıkta da temel nokta önyargısız şekilde gerçekleri algılayabilmek, böylece anı yaşayabilmektir. İnsancıl psikoterapi bilinçli farkındalıkla birlikte "gerçeklik" kavramının yaşanmasına olanak tanır.

\subsection{Varoluşçu Psikoterapi}

Varoluşçu psikoterapi her gün yinelenmesini tavsiye ettiği "Beş Anımsama"dan bahseder. Bu beş madde şu şekilde sıralanmaktadır (Ö̈zyeşil, 2011: 37):

1. Tabiatımda yaşlanmak var ve yaşlılıktan kaçamam.

2. Tabiatımda hastalanmak var ve hastalıktan kaçamam.

3. Tabiatımda ölüm var ve ölmekten kaçamam.

4. Tüm insanların tabiatında değişim vardır. Önem verdiğim ve sevdiğim bireylerle yollarımın ayrılmasını engellememin bir çözümü yoktur.

5. Gerçekleştirdiğim eylemler benim tek hakikatimdir ve bu eylemlerin sonuçlarından kaçmamın bir yolu yoktur.

$\mathrm{Bu}$ maddeler hayatın her yönüyle barışık olmamızı, korkularımızla başa çıkmamızı ve her şeye hazırlı olmamızı ögütler. Bu maddeler aynı zamanda içinde bulunulan anın yaşanmasını tetikler. Bilinçli farkındalığın temellendirildiği yönü de burasıdır.

\section{BİLINÇLİ FARKINDALIK KAVRAMININ BOYUTLARI VE KULLANIM ALANLARI}

Bilinçli farkındalı̆̆ı farklı yazarlar farklı şekillerde boyutlandırmışlardır. Bu çalışmada Marzono ve arkadaşları (1988) tarafından yapılan boyutlandırma esas alınmıştır. Marzono ve arkadaşları tarafından bilinçli farkındalık iki boyutta incelenmektedir. Bu boyutlar, kişinin kendisi hakkında ve süreç hakkında olan bilgisi ve bu bilginin kontrolü şeklinde isimlendirilmiştir. Şekil 1'de bu iki temel boyut ve onların alt boyutları gösterilmiştir (Demir ve Doğanay, 2009: 607). 


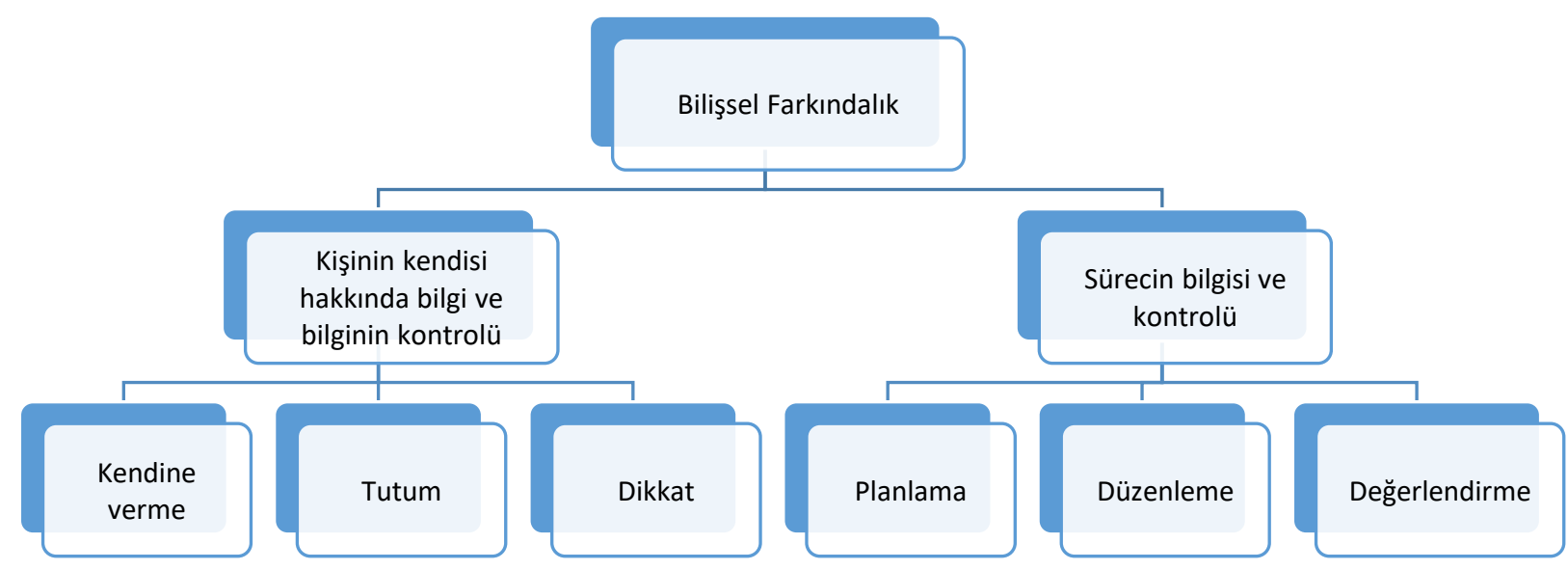

Bilinçli farkındalığın en çok üzerinde durulduğu alan, bilinçli farkındalıkta öğrenmeyi öğrenmenin temel alınması sebebiyle, öğrenme ile alakalı alanlardır. Öğrenme ile alakalı faaliyetlerden bir tanesi de okumadır. Kişinin ne okuduğunu en iyi şekilde anlaması, yorumlayabilmesi ve okuduklarından sonuçlar çıkarması bilinçli farkındalık stratejileri ile mümkün olabilmektedir (Akın ve Çeçen, 2014: 93).

Bilinçli farkındalığın önemli olduğu bir diğer alan ise sağlık sektörüdür. Toplumun hastalıklar konusunda ne kadar bilgi sahibi olduğu ve hastalıklarını ne kadar tanıdıkları hastalıklardan korunma ve tedavi süreçleri açısından oldukça önemlidir. Özellikle tedavisinin yüksek maliyetli olduğu hastalıklarda tedaviden ziyade önleyici çalışmalar ağırlık kazanmaktadır (Aksu vd., 2005: 37).

Farkındalık Temelli Terapiler (Mindfulness Based Therapies), ruh sağlığında kullanılan tedavi yöntemleridir. $\mathrm{Bu}$ yöntemde danışanların farkındalık seviyesini artırmaya yönelik teknikler kullanılmaktadır (Devrim Çatak ve Ögel, 2010: 86). Bu tekniklerle bilişsel ve yaşantısal sorunların üstesinden gelinmesi çalışmaları yapılmakta ve depresyon, yeme bozuklukları, madde bağımlılığı gibi problemlerin çözülmesinde kullanılmaktadır. Farkındalık temelli terapiler aracılı̆̆ 1 ile bireylerin yaratıc1lık, dikkat ve öğrenme seviyelerinin artırılması zihin, beyin, vücut, davranış ve zihinsel sağlığında iyileşme, beceri ve yaşam kalitesinde olumlu değişimler sağlanmaktadır. $\mathrm{Bu}$ olumlu gelişmelerin yanı sıra bazı olumsuz durumların yok edilmesi veya azaltılmasında da farkındalık temelli terapiler uygulanmaktadır. Stres, kayg1 ve depresyonun azaltılması, okuma zorlukları, ruhsal problemler, duyguların ifade edilememesi, kişilik çözünmesi, negatif duygu ve internet bağımlılığı tedavilerinde farkındalık temelli terapiler kullanılmaktadır. (Bektaş Öztaşkın, 2013: 148).

\section{BİLINÇLİ FARKINDALIKTAKI TEMEL TUTUMLAR}

Bilinçli farkındalıkta bazı tutumların sergilenmesi, öğrenme sürecinde başarıyı artırıcı veya engelleyici etkiye sahiptir. Kabat-Zinn (2001) tarafından bilinçli farkındalıktaki temel tutumlar şu şekilde ifade edilmiştir: Sabırlı olmak, akışına bırakmak, ön yargılı olmamak, güvenmek, cömert olmak, güçlü olmak, sade olmak, konsantre olmak ve vizyon sahibi olmaktır.

\subsection{Sabırlı Olmak}

Sabır, dışarıdan empoze edilebilen, yasayla veya alınan kararlar doğrultusunda uygulanabilen bir tutum değildir. Sabır, bilgeliğin bir türüdür. Sabırlı birey, her şeyin bir zamanı olduğunu ve bu zamanda gerçekleşeceğini kabul etmektedir ( Özyeşil, 2011: 40).

Bilinçli farkındalıkta temel etik tutumlardan biri sabırdır. Sabırlı davranılırsa, uygulanan farkındalık temelli meditasyon uygulamaları daha yavaş ve olgunlaşarak devam edecektir. Sabırlı davranıldığı sürece her şey zamanla çözülecektir. Aceleci olmak çoğunlukla işe yaramamanın yanı sıra, acı çekmeye sebebiyet verebilmektedir.

Farkındalık terapilerinde sabrın kalitesi geliştirilerek, her nefesin akışının farkına varılması sağlanır. Nasıl ki olaylar kendi doğasına göre ortaya çıkıyorsa, hayatın da aynı şekilde ortaya çıkmasına müsaade edilmelidir (Bishop vd., 2004: 235). 


\subsection{Salıvermek}

Salıvermek, sadece "söylenen şey" anlamına gelir. Diğer bir ifade ile bir şeye tutunmayı sona erdirme davetidir ki bu bir fikir, bir şey, bir olay, belirli bir zaman veya bir manzara ya da bir arzu olabilir. Bu şey ortaya çıktıkça mevcut anın akışına tam kabul ile ve bilinçli şekilde salıvermek yani her şeyi akışına bırakmak gerekir. Ortaya çıkan şeyle çekişmeden, direnmeden ya da mücadele etmeden, bir şeylerin cazibesine kapılmadan veya reddetmeden ortaya çıkan şeylerden vazgeçmek veya istemek anlamına gelir. Bu durum elde tutulan bir şeyi yok etmek için avucun açılmasına izin vermeye benzetilebilir (Kabat-Zinn, 2001).

Salıvermek sadece dış olaylar için geçerli değildir. Bireyler çoğu kez kendine takılı kalmaktadır. Salıvermek, bireyin hoşuna giden veya sevmediği şeylere şeffaf olmayı seçmesini ifade eder. Diğer bir ifade ile düşüncelere izin verme yeteneğidir ki bu durum kişinin aklını, içeriğini ve süreçlerini kontrol edilemez olarak görme eğiliminin temelini oluşturur (Williams, 2008: 724).

\subsection{Yargılayıcı Olmamak}

Beynimizin bir bölümü deneyimlerimizi sürekli olarak değerlendirir, diğer deneyimlerle karşılaştırır ve tutar. Beyinde tutulan bu bilgiler ışı̧̆ında bazı beklentiler ortaya çıkar. Önyargılarımız genellikle olumsuz tutumlar geliştirmemize neden olur. Örneğin birey yeterince iyi olmadığını, kötü şeyler yaşayacağını, iyi şeylerin fazla uzun sürmeyeceğini, diğer insanların kendisini incitebileceğini, istediği şekilde yol alamayacağını, hiçbir şey bilmeyen sıradan biri olduğunu düşünme eğilimindedir. Kısacası birey dünyayı renkli bir gözlügün ardından görür. Bu gözlüğün ardından gördüğü şey iyiyse hoşuna gider, kötü ise hoşlanmaz (Kabat-Zinn, 2001).

Yargılayıcı olmama veya bilinçli yargılamama kavramı, tarafsızlığı belirtir. İyi/kötü, doğru/yanlış veya değerli/değersiz gibi değer biçen etiketlerin uygulanmasını reddeder. Bir deneyimden kaçınmayı ya da değiştirmeyi denemeden olduğu gibi yaşamaya izin vermeyi gerektirir. Farkındalık, olayları yargılamamayı teşvik eder, olayları yargılamanın aksine hem olayların hem de olayların beraberinde getirdiği süreçlerin olduğu gibi kabul edilmesini öngörür (Wahbeh vd., 2011: 220).

\subsection{Güvenmek}

Güven, her şeyin düzen ve bütünlügünü temsil eden bir kavramdır. Birey kendine ya da başka bir şeye veya bir sürece, ideale güvendiğinde bu güvende güçlü bir dengeleyici unsur bulabilecektir. $\mathrm{Bu}$ güven sezgisel olarak bireye rehberlik eder ve bireyi dışarıdan gelecek zararlardan veya bireyin kendisine zarar vermesinden korur (Kabat-Zinn, 2001).

Güven duygusu bilinçli farkındalığın geliştirilmesinde önemlidir. Farkındalık tanımı içerisindeki anlamı dikkate alındığında güvenin, özel deneyimle temas halinde kalma becerisine olan güven anlaşılmalıdır (Bishop vd., 2004: 235). Daha geniş bir ifade ile birey gözlemleme yeteneğine, derinlemesine bir şey öğrenebilme yeteneğine güvenmeli, kendisine derinlemesine bakmalı ve güvenmelidir. Birey öncelikle bulunduğu anda hissettiklerini, düşündüklerini ve gördüklerini kabullenmelidir. Zamanla doğru sezgileri seçecek ve bu sezgilerinin güvenine layık olduğuna inanacaktır.

\subsection{Cömertlik}

Cömertlik de sabır, salıverme, yargılayıcı olmama veya güven gibi bir başka bilinçli farkındalık tutumudur ve dikkatli olabilmek için önemli bir temel oluşturur. Cömertlik, bireyin kendi kendini gözlemlemesi ve sorgulaması için önemli bir araçtır. Cömertliğe başlamak için en iyi yer bireyin kendisidir.

Tutumların yalnızca insanların ekonomik faaliyetleri için değil, aynı zamanda kişisel refahları, kişilerarası ilişkileri, başkalarının refahı ve çevresel olarak da önemli sonuçları vardır. Cömertlik, bireylerin varlıklarını paylaşma dereceleriyle ilgilidir. Cömert insanlar düşünülenden fazlasını dağıtmaya veya paylaşmaya isteklidir ve kendi kişisel kazançları azalsa bile diğer insanlara yardım edecek yaşam seçimleri yaparlar. Daha az cömert insanlar, aksine, daha az paylaşırlar ve başkaları üzerindeki olumlu etkilerini çok az önemserler. Cömertlikte bahsi geçen paylaşım para veya herhangi bir maddi mülkiyet değildir. Aksine bu tutumda önemli olan en iyi benliğin, coşkunun, canlılığın, ruhun, 
güvenin, açıklığın ve en önemlisi bireyin varlığını çevresindeki bireylerle, kendisiyle ve asıl ailesiyle ve nihayetinde dünya ile paylaşmasıdır (Kasser, 2005: 358-359).

\subsection{Güçlü Olmak}

Bireyin kendisini yetersiz, güvensiz ya da incinmiş hissetmesi, savunmasız olduğunu düşünmesine neden olur. Bu düşünce ise hem kendisine hem de çevresindeki bireylere acı verir.

Bilinçli farkındalık ile birey, her şeyi kontrol altında tutar ve her şeyi tepkisel duygulara kapılmadan halletmeye yetecek kadar akıllı olan, son derece etkilenemez bir tutum sergilemeye başlayabilir. Her bireyin duygusal bir hayatı vardır. Bireyin öncelikle kendi tehlikesinden kurtulması gerekir (Kabat-Zinn, 2001).

Bilinçli farkındalıkta temel nokta anı yaşamak ve kabullenmektir. Gerçekten güçlü birey gücünü kendisine veya başkalarına vurgulama ihtiyacı duymaz. Gerçekten güçlü birey her şey hakkında fikir sahibi olmak zorunda da değildir. Güçlü bireylerin de zaman zaman yardıma ihtiyacı olabilir, duygusal desteğe ihtiyaç duyabilir, güçlü bireylerin de zor zamanları olabilir ve onların da hisleri vardır, ağlayabilir, başkalarına yenilmez görünmeye çalışmaz ve duyguları her zaman açıktır. Zayıflığa benzeyen bu özellikler aslında bireyin gücünün yattığı yerdir (Key, 2004: 68-69).

\subsection{Sadelik}

İçimizdeki bir dürtü sürekli başka şeyleri içinde bulunulan ana dâhil eder. Birey zamanla bu dürtülere "hayır" demeyi ögrenmelidir çünkü bilinçli farkındalık geçmişte veya gelecekte değil, içinde bulunulan anda yaşamayı gerektirir. Yaşanmışlıklar geçmişte kalmıştır, geleceğin ise nasıl ve ne şekilde yaşanacağı, hatta yaşanıp yaşanmayacağı bile belirsizdir. İçinde bulunulan zamanı geçmiş ve gelecekle doldurmak, o sürenin boşa harcanmasına ve bireyin bilinçsiz kalmasına sebep olur (Sayın, 2012: 185). $\mathrm{Bu}$ dürtülerin karşılanabilmesi için basit olunmalıdır. Bir kerede kasıtlı olarak tek bir şey yapılmalı ve o şey için orada olunduğundan emin olunmalıdır. Sadelik bir günde daha az yer kaplamaktan ziyade bireyin daha fazlasını görebilmesi, daha fazlasını yapabilmesi ve daha fazlasını yapabileceği anlamını taşımaktadır.

Her şeyi parçalamak, sadeliği sağlamanın en önemli kısmıdır. Nesnel olarak var olan olayların ayrımını yapabilmek, farkındalık için bir kriter olarak kabul edilebilir. Düşünme, öğrenme ve karar verme süreçlerinin düzenlenerek işlevlerin ayrımının yapılabilmesi oldukça önemlidir (Hoffstaedter, 2008: 22). Aklınıza ve bedeninize telefona cevap vermek yerine çocuğunuzla vakit geçirmeye devam etmesini, iç dürtülerinize tepki göstermemeyi seçmesini söyleyebilirsiniz. Ya da bir akşam sadece oturarak hiçbir şey yapmamayı veya kitap okumayı ya da yürüyüşe çıkmayı seçebilirsiniz.

Hayatınızı sade tutmak için öncelikle "hayır" diyebilmek önemlidir. Bunu yapabilmek bile tek başına zorlu bir disiplindir ve gayrete değer. Sadelik, neyin önemli olduğunu, her şeyin birbirine bağl1 olduğunu ve her seçimin geniş kapsamlı sonuçları olduğunu hatırlatır. Mümkün olduğunca sadeliğin seçilmesi en derin özgürlük unsurunu ve aslında bireyin daha fazlası olabileceğini keşfetmesi için bir firsat sunar.

\subsection{Konsantrasyon}

Konsantrasyon, farkındalığın köşe taşıdır. Bireyin dikkati sadece zihnin sakin ve istikrarlı olduğu kadar güçlü olabilmektedir. Konsantrasyon, bir gözlem nesnesine sarsılmaz bir dikkati sürdürmek için kullanılan zihin kapasitesidir.

Konsantrasyon nefese odaklanır ve kişinin odağını sınırlandırarak geliştirilir. Konsantrasyon çalışmaları yapan Samadhi, yürüyüşe çıkar ve gezinirken her seferinde dikkatini sürekli nefese geri getirerek konsantrasyon yetisini geliştirir ve derinleştirir. Nefes, bedensel farkındalığın geliştirilmesinde kullanılan bir meditasyon nesnesidir ve farkındalığın geliştirilmesinde çok önemli bir rol oynamaktadır. Nefes alıp verme uygulamaları zihinsel ve fiziksel fenomenlerle ilgili derinlemesine içgörü deneyimi sunar (Virtbauer, 2017: 52)

Bir bireyin enerjisi yalnızca nefesini yaşamaya, bu nefesin dışarı çıkmasına veya bunun gibi başka tek bir nesneye dikkati yöneltmeye uygundur. Konsantrasyon uygulamalarının beraberinde 
getirdiği durağanlık ve sakinlik, farkındalık kültürünün temelini oluşturmaktadır. Konsantrasyon ne kadar derin olursa, farkındalık potansiyeli de o kadar derin olur.

\subsection{Vizyon}

Neden yaptığınızı, hayatınızdaki değerinin neye benzediğini, bunun neden sizin yolunuz olabileceğini bilmediğiniz bir uygulamaya kendinizi vermeniz neredeyse imkânsızdır. Doğu kültürlerinde meditasyon olarak kullanılan farkındalık uygulamalarına Batı kültürlerinde daha az destek verilmektedir. Yaşamınızın, aklınızın hatta bedeninizin daha sakin ve daha açık olması, hatta sabahın erken saatlerinde kalkıp sabahın soğuk ve karanlık olduğu saatlerde kendi kendinize oturup içinde bulunduğunuz anı yaşamanız, Batı kültüründe ikincil önem derecesinde görülecektir.

Yaşamınızı uzun vadede kararlı bir şekilde sürdürmeyi diliyorsanız bir vizyona ihtiyacınız olacaktır. Sadece dinamik bir vizyonun gücü ve yaydığı motivasyon, her geçen gün bu yolda devam edebilecek, her gün pratik yapma isteğine ve neler olup bittiğine bakma farkındalığını yaratacak enerjiyi sağlayacaktır (Kabat-Zinn, 2001).

\section{BİLINÇLİ FARKINDALIK ÍLE ÍLGILII ULUSAL YAZINDA YAPILMIŞ BAZI ARAŞTIRMALAR}

Bilinçli farkındalık kavramı ele alınarak yapılan çalışmalar incelendiğinde, kavramın daha ziyade eğitim bilimciler, psikologlar ve psikiyatristler tarafından araştırmalara konu edildiği görülmektedir. Bunun yanı sıra, örgütsel davranış alanına giren nadir birkaç çalışma da karşımıza çıkmaktadır. Aşağıda bu çalışmalardan bazıları hakkında kısa bilgilendirmeler yapılmıştır.

Akıllılar (2013) yaptığı çalışmada ikinci yabancı dil olarak Almanca öğreniminde bilinçli farkındalık üzerine çalışmıştır. Yapılan çalışmada İngilizce öğreniminin, ardından yapılan Almanca öğrenimini kolaylaştırdığı, Almanca öğreniminde İngilizceden yapılan çağrışımların iki dil arasında olumlu bir etkileşime neden olduğu belirlenmiştir. Akın ve Çeçen (2014), ortaokul öğrencileri üzerinde yaptıkları çalışmada öğrencilerin okuma stratejileri bilinçli farkındalık düzeylerinin yüksek olduğu bulgusunu elde etmişlerdir. Yine aynı çalışmada genel okuma stratejisindeki artışın problem çözme stratejisini artırdığı belirlenmiştir. Kana (2014) yaptığı aynı konulu çalışmada örneklemi yaş, cinsiyet ve ailelerin okuma düzeyine göre incelemiştir. Bağçeci ve arkadaşlarının (2011) aynı yaş grubu üzerinde yaptıkları başka bir çalışmada ise öğrencilerin bilinçli farkındalık düzeyleri ile seviye belirleme sınavı ve yılsonu başarı puanlarından oluşan akademik başarıları arasındaki ilişki incelenmiş, bilinçli farkındalığın sınav sonuçlarını pozitif yönde etkilediği bulgusuna ulaşılmıştır. Benzer yaş gruplarında yapılmış olan çalışmalardan bir diğeri de Bektaş Öztaşkın'ın (2013) sosyal bilgiler dersinde belgesel film kullanımı üzerine yapmış olduğu çalışmadır. Bu çalışmada sosyal bilgiler derslerinde izletilen belgesel filmlerin bilinçli farkındalık düzeyini olumlu yönde etkilediği sonucu elde edilmiştir. Demir ve Doğanay 2010'da yaptıkları çalışmada altıncı sınıf öğrencileri üzerinde bilişsel koçluk yöntemi aracılığı ile öğretilen bilişsel farkındalık stratejilerinin sosyal bilgiler dersi hakkında bilişsel farkındalık becerileri ve kalıcılığa etkisini ele almışlardır. Yapılan çalışmada koçluk faaliyetlerinin hem öğrenciler hem de öğretmenler üzerinde olumlu etkileri bulunmuştur.

Demir (2015) tarafından yapılan çalışmada, öğrencilerin aldıkları bilinçli farkındalık temelli kognitif terapi programı sayesinde, depresif belirti düzeylerinin anlamlı şekilde azaldı $\breve{g} 1$ bulgusuna ulaşılmıştır. Ögel ve arkadaşları (2014) tarafından gerçekleştirilen başka bir çalışmada bağımlı olan ve olmayan bireyler incelenmiş olup, bağımlılıkta farkındalık terapisinin yararlı olabileceği sonucuna ulaşılmıştır. Deniz ve arkadaşları (2017)'de gerçekleştirdikleri çalışmalarında, öğrencilerin bilinçli farkındalıklarının artmasının onların duygusal zekâlarını yükselttiğini ve bu yükselişle birlikte psikolojik iyi oluşlarının da güçlendiğini bulgulamışlardır. Demir (2017), üniversite öğrencileri üzerinde gerçekleştirdiği çalışmada, bilinçli farkındalık temelli bilişsel teknikler kullanılarak yapılan terapi programının uygulama yapılan öğrencilerin kaygı düzeylerinin düşmesine sebep olduğunu gözlemlemiş̧tir. Demir ve Gündoğan (2018) tarafından yapılan çalışmada ise, yapılan analizler bilinçli farkındalık temelli bilişsel terapi programının üniversite öğrencilerinin duygu düzenleme güçlüklerini azaltmada etkili olduğunu göstermiştir.

Karavardar (2015) İstanbul'da bir üretim işletmesinde gerçekleştirdiği çalışmada, bilinçli farkındalık ile iş-aile dengesi ve iş performansı arasında pozitif yönde bir ilişki belirlenmiştir. 
Karacaoğlan ve Şahin (2016)'in Ankara'da görev yapan kamu ve özel sektör çalışanları ile gerçekleştirdikleri araştırmada, bilinçli farkındalığın iş tatminini anlamlı bir şekilde yordadığı sonucuna ulaşılmıştır. Aşkun Çelik ve Çetin (2014)'in önlisans ve lisans seviyesinde öğrenim gören üniversite öğrencileri örnekleminde gerçekleştirdikleri çalışmada, bilinçli farkındalığın yapıcı ve olumlu çatışma çözme süreçleri açısından önemli rolü olduğunu ortaya çıkarılmıştır.

Sağlık konusunda bilinçli farkındalık üzerine çalışma yapan Aksu ve arkadaşları (2005), eğitim seviyesi ile osteoporoz farkındalık düzeyini ölçmüşlerdir. Yaptıkları çalışmada halkın çoğunluğunun bu hastalık hakkında bilgi sahibi olmadığı, ancak eğitim seviyesi dikkate alındığında eğitim seviyesi yüksek bireylerin hastalık hakkında daha fazla bilgiye sahip olduğu sonucuna ulaşılmıştır. Sağlık konusunda yapılmış olan dikkat çekici çalışmalardan bir diğeri ise Gölge ve arkadaşları (2011) tarafından yapılmış olan 'sağlık çalışanlarının çocuk istismarı ve ihmali konusundaki farkındalık düzeylerinin ölçülmesi' başlıklı çalışmadır. Yapılan çalışmada, sağlık çalışanlarının çocuk istismarı ve ihmali hususunda yeterli farkındalık düzeyinde olmadıkları belirlenmiştir. Yine aynı çalışmanın sonuçları geçmiş çalışmalarla kıyaslandığında bu konuda herhangi bir gelişme yaşanmadığı görülmüş̧ür.

\section{SONUÇ}

Bireylerin yaşamlarının her alanında, eğitimde, sağlıkta, kendilerini tanımalarında ve istedikleri şekilde yönlendirebilmelerinde bilinçli farkındalık önemli rol oynamaktadır. Bireyler bilinçli farkındalık sayesinde kendilerini, iyi ve kötü, güçlü ve zayıf yönlerini tanıyarak planladıkları sonuçlara ulaşabilmektedirler. İstenilen süreci planlamak, yürütmek, kontrol etmek ve dilenilen şekilde düzenlemek ancak farkındalıkla mümkündür.

Bilinçli farkındalık yeteneği yüksek olan bireyler aynı zamanda öz-yeterlilikleri, öz-yönetimleri ve öz-düzenlemeleri yüksek olan bireylerdir. Bu bireyler kendilerini kontrol etme ve diledikleri şekilde düzenleme yaparak yönlendirme yeteneğine sahiptirler. Diğer yandan bilinçli farkındalık yeteneğine sahip olabilmek için birey öncelikle sabırla kendisini tanımaya çalışmalı, olayları zamana ve akışına bırakmalıdır. Önyargılarından arınmış birey kendisine, sürece ve ideallerine güvenmeyi de öğrenmelidir.

Bilinçli farkındalıkta önemli özelliklerden bir diğeri de bireyin düşündüğünden fazlasına sahip olduğunu kabullenerek daha güçlü olması, zayıflık göstermemesidir. Geçmişte veya gelecekte değil de anda yaşayan bireyin tüm bunları neden yaptığını bilmesi ve ana konsantre olması en önemli noktalardandir.

Bu çalışmada bilinçli farkındalık kavramı hakkında kavramsal bir inceleme gerçekleştirilmiştir. Türkçe alanyazın incelendiğinde, üzerinde yaklaşık 10 yıldır çalışmalar gerçekleştirilen kavramın daha ziyade eğitim ve psikoloji alanlarında kullanıldığı gözlemlenmiştir. Örgütsel davranış alanı açısından yapılan çalışmalar incelendiğinde ise bir elin parmaklarını geçmeyecek kadar bir çalışma karşımıza çıkmaktadır. Bu kapsamda psikolojik dayanıklılık, psikolojik ve öznel iyi oluş, iş ve yaşam doyumu, duygusal zekâ, tükenmişlik, görev ve bağlamsal performans gibi değişkenler ile bilinçli farkındalık arasındaki ilişkilerinin incelenmesi, bundan sonra bu kavramı çalışacak araştırmacılara önerilebilir.

Örgütler açısından değerlendirme yapıldığında ise, bilinçli farkındalık düzeyi yüksek olan çalışanların kendine ve dolayısıyla örgüte katkılarının fazla olacağı aşikardır. Bu noktada örgütlerin, çalışanlarının bilinçli farkındalık seviyelerini artırıp, anda kalmalarını sağlayacak önlemler almaları gerekmektedir. Örneğin, çalışanların işyerinde ya da iş dışında başka bir ortamda bilinçli farkındalık eğitimleri almaları sağlanabilir. Bu sayede onların stresle daha kolay baş etmesi ve dolaylı olarak verimliliklerinin ve performanslarının artması beklenebilir. Bilinçli farkındalık eğitimlerine katılan çalışanların daha mutlu, daha yaratıcı, kontrolünü kaybetmeyip sakinliğini koruyabilen ve zor anlarda etkin kararlar alabilen bir yapıya bürünmeleri mümkün olabilecektir. Tüm bunlar ise 21. yüzyılın en önemli gücü olan beşeri sermayenin çok daha etkili kullanılabilmesine yardımcı olacaktır. 


\section{KAYNAKÇA}

Akıllılar, T. (2013). İkinci yabancı dil olarak Almanca öğreniminde üstbilişsel farkındalık. Uşak Üniversitesi Sosyal Bilimler Dergisi. 14, 275-285.

Akın, A., Abacı, R., \& Çetin, B. (2007). Bilişötesi Farkındalık Envanteri'nin Türkçe formunun geçerlik ve güvenirlik çalışması. Kuram ve Uygulamada Eğitim Bilimleri. 7(2), 655-680.

Akın, E., \& Çeçen, M. A. (2014). Ortaokul öğrencilerinin okuma stratejileri üstbilişsel farkındalık düzeylerinin değerlendirilmesi: Muş Bulanık örneği. Turkish Studies. 9(8), 91-110.

Aksu, A., Zinnuroğlu, M., Karaoğlan, B., Akın, S., Kutsal, Y. G., Atalay, F., \& Dinçer, G. (2005). Osteoporoz, eğitim durumu ve farkındalık düzeyi araştırma sonuçları. Osteoporoz Dünyasindan, 11(1), 36-40.

Bağçeci, B., Döş, B., \& Sarıca, R. (2011). İlköğretim öğrencilerinin üstbilişsel farkındalık düzeyleri ile akademik başarısı arasındaki ilişkinin incelenmesi. Mustafa Kemal Üniversitesi Sosyal Bilimler Enstitüsü Dergisi, 8(16), 551-566.

Bektaş-Öztaşkın, Ö. (2013). Sosyal bilgiler derslerinde belgesel film kullanımının akademik başarıya ve bilinçli farkındalık düzeylerine etkisi. Ĕgitim Bilimleri Araşstırmaları Dergisi. 3(2), 147-162.

Bishop, S. R., Lau, M., Shapiro, S., Carlson, L., Anderson, N. D., Carmody, J., ... \& Devins, G. (2004). Mindfulness: A proposed operational definition. Clinical Psychology: Science and Practice. 11(3), 230-241.

Brown, K. W., \& Ryan, R. M. (2003). The benefits of being present: Mindfulness and its role in psychological well-being. Journal of Personality and Social Psychology. 84(4), 822-848.

Çatak, P. D., \& Ögel, K. (2010). Farkındalık temelli terapiler ve terapötik süreçler. Klinik Psikiyatri. 13, 85-91.

Çelik, D. A., \& Çetin, F. (2014). Kişilerarası çatışma çözme yaklaşımlarında bilinçli farkındalık ve özbilinç'in rolü. Research Journal of Business and Management. 1(1), 29-38.

Demir, Ö., \& Doğanay, A. (2009). Bilişsel farkındalık becerilerinin geliştirilmesinde bilişsel koçluk yaklaşımı. Kuram ve Uygulamada Eğitim Yönetimi Dergisi. 15(4), 601-624.

Demir, Ö., \& Doğanay, A. (2010). Bilişsel koçluk yöntemiyle öğretilen bilişsel farkındalık stratejilerinin altıncı sınıf sosyal bilgiler dersinde bilişsel farkındalık becerilerine ve kalıcılığa etkisi. Illkögretim Online. 9(1), 106-127.

Demir, V. (2015). Bilinçli farkındalık temelli kognitif terapi programının bireylerin depresif belirti düzeyleri üzerine etkisi. Psikoloji Çalışmaları. 35(1), 15-26.

Demir, V. (2017). Bilinçli farkındalık temelli bilişsel terapi programının üniversite öğrencilerinin kayg1 düzeylerine etkisi. OPUS-Uluslararası Toplum Araştırmaları Dergisi. 7(12), 98-118.

Demir, V., \& Gündoğan, N. A. (2018). Bilinçli farkındalık temelli bilişsel terapi programının üniversite öğrencilerinin duygu düzenleme güçlüklerini azaltmadaki etkisi. Ege Eğitim Dergisi. 19(1), 4666.

Deniz, M. E., Erus, S. M., \& Büyükcebeci, A. (2017). Bilinçli farkındalık ile psikolojik iyi oluş ilişkisinde duygusal zekânın aracılık rolü. Türk Psikolojik Danışma ve Rehberlik Dergisi. 7(47), $17-31$.

Dilci, T., \& Kaya, S. (2012). 4. ve 5. sınıflarda görev yapan sınıf öğretmenlerinin üstbilişsel farkındalık düzeylerinin çeşitli değişkenler açısından incelenmesi. Süleyman Demirel Üniversitesi FenEdebiyat Fakültesi Sosyal Bilimler Dergisi. 27, 247-267.

Doğanay, A., \& Demir, Ö. (2011). Akademik başarısı düşük ve yüksek öğretmen adaylarının ders çalışma sırasında bilişsel farkındalık becerilerini kullanma düzeylerinin karşılaştırılması. Kuram ve Uygulamada Ĕgitim Bilimleri. 11(4), 2021-2043. 
Gölge, Z. B., Hamzaoğlu, N., \& Türk, B. (2012). Sağlık çalışanlarının çocuk istismarı ve ihmali. Adli Tip Dergisi. 26(2), 86-96.

Hoffstaedter, F. (2008). Bewusstsein als psychologisches konstrukt und seine operationalisierbarkeit, Doktora Tezi, Köln Üniversitesi, Köln.

Kabat-Zinn, J. (2001). Mindfulness meditation for everyday life. London: Piatkus Books.

Kana, F. (2014). Ortaokul öğrencilerinin üstbiliş okuma stratejileri farkındalık düzeyleri. Erzincan Üniversitesi Eğitim Fakültesi Dergisi. 16(1), 100-120.

Karacaoğlan, B., \& Şahin, N. H. (2016). Bilgece farkındalık ve duygu düzenleme becerisinin iş tatminine etkisi. Iş̧letme Araştırmaları Dergisi. 8(4), 421-444.

Karakelle, S., \& Saraç, S. (2007). Çocuklar İçin Üst Bilişsel Farkındalık Ölçeği (ÜBFÖ-Ç) A ve B formları: Geçerlik ve güvenirlik çalışması. Türk Psikoloji Yazıları. 10(20), 87-103.

Karasakaloğlu, N., Karacaloğlu, A. S., \& Özelçi, S. Y. (2012). Türkçe öğretmeni adaylarının okuma stratejileri, eleştirel düşünme tutumları ve üst bilişsel yeterlilikleri. Ahi Evran Üniversitesi Kırşehir Eğitim Fakültesi Dergisi. 13(1), 207-221.

Karavardar, G. (2015). İş yaşamında farkındalık: iş-aile dengesi ve iş performansı ile ilişkisi. Yönetim ve Ekonomi Araştırmaları Dergisi. 13(1), 186-199.

Key, K. D. M. (2004). How strong is too strong? Implications for the well -being of college-educated African-American women. Doktora Tezi, Pepperdine University, Malibu, CA.

Kuyumcu, B. (2012). Türk ve İngiliz üniversite öğrencilerinin psikolojik iyi oluş duygusal farkındalık ve duygularını ifade etmelerinin ülke ve cinsiyet değişkenlerine göre incelenmesi. Erzincan Üniversitesi Eğitim Fakültesi Dergisi. 14(2), 1-24.

Ögel, K., Sarp, N., Gürol, D. T., \& Ermağan, E. (2014). Bağımlı olan ve olmayan bireylerde farkındalık (mindfulness) ve farkındalığı etkileyen etkenlerin incelenmesi. Anadolu Psikiyatri Dergisi. 15(4), 282-288

Özsoy, G. (2008). Üstbiliş. Türk Eğitim Bilimleri Dergisi. 6(4), 713-740.

Özyeşil, Z. (2011). Üniversite öğrencilerinin öz-anlayış düzeylerinin bilinçli farkındalık kişilik özellikleri ve bazı değişkenler açısından incelenmesi. Doktora Tezi, Selçuk Üniversitesi Eğitim Bilimleri Enstitüsü, Konya.

Sayın, E. (2012). Tasavvuf ve psikoloji açısından İbnü'l-Vakt anlayışının etkileri. Marife Dini Araştırmalar Dergisi. 3, 177-190.

Taylor, S. (1999). Better learning through better thinking: Developing students' metacognitive abilities. Journal of College Reading and Learning. 30(1), 34-45.

Ülev, E. (2014). Üniversite öğrencilerinde bilinçli farkındalık düzeyi ile stresle başa çıkma tarzının depresyon, kaygı ve stres belirtileriyle ilişkisi. Yüksek Lisans Tezi, Hacettepe Üniversitesi Sosyal Bilimler Enstitüsü, Ankara.

Virtbauer, G. (2017). Atem, embodiment und gesundheit: Eine philosophisch psychologische interpretation zur buddhistischen atemmeditation (ānāpāna-sati). SFU Forschungsbulletin. 5(1), 49-58.

Wahbeh, H., Lu, M., \& Oken, B. (2011). Mindful awareness and non-judging in relation to posttraumatic stress disorder symptoms. Mindfulness. 2(4), 219-227. 